\title{
Exchange Rate Volatility in the Covid-19 Period: An Analysis Using the Markov-Switching ARCH Model
}

\author{
Havva Koç*
}

\section{Abstract}

Most analyses of exchange rate volatility in the economic literature are conducted by means of autoregressive conditional heteroskedasticity $(\mathrm{ARCH})$ or generalized ARCH (GARCH) models. According to Humilton and Susmel such models often predict higher volatility than their actual volatility rates, and their predictive performance is considerably low. Diebold and Lamoureux and Lastapes attributed this to the structural change in the ARCH process. Moreover, Hamilton and Susmel developed the Markov-switching ARCH (MS-ARCH or SWARCH) model to overcome the reliability problem of parameter estimates that do not allow for a regime change. This method presents a nonlinear structure enabling regime changes. Therefore, the MS-ARCH method was preferred in the study.

Considering the continuing massive impact of COVID-19 on the global financial system, its influence on exchange rates must also be explored. This question was addressed in the analysis. In this direction, the effect of volatility was estimated with the MS-ARCH model using the return values of USD/TRY exchange rate in the trading days between March 2020 and October 2021, the month March 2020 when the first COVID-19 case appeared in Turkey. Two volatility regimes, namely, low volatility and high volatility, were employed in the study. The findings demonstrate that the COVID-19 pandemic, along with various economic and political events in Turkey and the world, affects exchange rate volatility and that these volatility periods are permanent. It also depicts that the USD/TRY return series has high volatility and a strong regime dependency.

From these results, it may be concluded that the forecasting of information on exchange rate volatility is important for asset pricing and risk management because exchange rate volatility can increase transaction costs and reduce gains in international trade. The article contributes to the existing body of literature by explaining volatility modeling in the light of the recent daily exchange rate returns during the COVID-19 pandemic.

\section{Keywords}

COVID-19, Monetary Policy, Exchange Rate, Volatility, MS-ARCH

\section{JEL Classification}

B23, C5, C32, F31, F37, G1, G17

* Corresponding author: Havva Koç (Ph.D. student), Trakya University, Institute of Social Sciences, Department of Economics, Edirne, Turkey. E-mail: havvakoc@trakya.edu.tr ORCID: 0000-0002-0906-1438

To cite this article: Koc, H. (2021). Exchange Rate Volatility in the Covid-19 Period: An Analysis Using the Markov-Switching ARCH Model. EKOIST Journal of Econometrics and Statistics, 35, 205-220. https://doi.org/10.26650/ekoist.2021.35.1011709 


\section{Introduction}

It is evident that infectious diseases have changed the world economy and politics, causing wars, socio-political changes, etc. throughout history. In the last months of 2019, COVID-19, a globally effective virus that broke out, brought almost half of the world to a standstill while eroding a quarter of wealth in about a month and affecting the financial markets in several implicit ways. Its effect persisted during the last months of 2021, i.e., the time period in which this study was conducted.

Before the onset of the COVID-19 pandemic, the global economy had been struggling to recover from the enduring impact of rising trade protectionism, trade disputes between major trading partners, falling commodity and energy prices, and economic uncertainties in Europe. Besides impacting human life significantly, the COVID-19 pandemic continues to have severe economic repercussions and poses one of the most serious uncertainties. This economic turbulence caused by the pandemic poses further risks in and threatens to increase the volatility of financial markets and corporate decision-making processes. Evaluating the state of the US economy, the Federal Open Market Committee stated: "The ongoing public health crisis will put heavy pressure on economic activity, employment and inflation in the short term and will pose significant risks to the economic outlook in the medium term" (Weiss, Schwarzenberg, Nelson, Sutter, and Sutherland, 2020).

In terms of financial markets, stock markets are indicators of economic, political, social, and cultural developments. Moreover, exchanges can react quickly to emerging information. The declines in the indices show the uncertainty and increasing risks in the economies. The COVID-19 pandemic started to increase in countries, and the rapid increase in the number of cases and deaths posed a great threat to the economies. The spread of the pandemic outside China and in Europe (especially in Italy and Spain), USA, France, and England, the closure of workplaces to prevent the pandemic, and implementation of strict measures, such as curfews, have increased risk perception in global markets. Situations such as the inability to find drugs and vaccines for the COVID-19 virus, the rapid spread of the pandemic worldwide, and the lack of complete knowledge of the prevention methods led to strong sales waves in stock markets, and historical declines were experienced (Şenol, 2020).

The COVID-19 pandemic has started to limit economic activities in Turkey as of March 2020. Its impact on economic activities deepened in April 2020. Moreover, some sectors slowed down and some came to a standstill due to the pandemic. This situation put pressure on the real sector, and the demand for precautionary liquidity in the economy increased. As in many countries, Turkey's policymakers have taken comprehensive policy steps to minimize the effects of the pandemic and eliminate its negative effects (Y1ldiz-Contuk, 2021). Although the central banks took the necessary steps to provide liquidity, they took measures to support the households 
and companies most affected by the pandemic on the fiscal policy side. However, the measures taken to prevent the effects of the pandemic continue to negatively affect individual consumption habits, production processes, and employment.

The Central Bank, which is responsible for monetary policy in Turkey, has had three changes of chairman from 2019 to October 2021, the date of this article. Sharp rises occurred in the exchange rate each time the chairman changed. As the COVID-19 pandemic continues, uncertainties regarding exchange, interest, and inflation rates also continue in the Turkish economy. The Turkish Lira, which has depreciated against the US dollar and euro for a long time, depreciates against all emerging market currencies in 2021. The first two are the Russian ruble and the Chinese yuan.

Financial time series, such as the exchange rate, often exhibit the phenomenon of volatility clustering, that is, periods when prices fluctuate widely over a long time, followed by calm. This volatility in exchange rates has been a constant source of concern for policymakers and academics alike, especially after the termination of the Bretton Woods agreements. Indeed, volatility information is important because the exchange rate risk can increase transaction costs and reduce gains from international trade. Policymakers need accurate predictions of exchange rate values. This is because exchange rate volatility is a useful measure of uncertainty about a country's economic environment (Epaphra, 2016).

Volatility is measured by the standard deviation or the variance of returns. It is often used as a rough measure of the total risk of financial assets. Many value-atrisk models for measuring market risk require an estimate of a volatility parameter (Epaphra, 2016).

The motivation for this study is how COVID-19 affects exchange rates, considering how it has and continues to affect the global financial system. An answer to this question was sought in the analysis. To capture the possible effects of COVID-19, this study analyzed the Turkish Lira (TL)-US dollar exchange rate data covering the trading days between 02.03.2020 and 11.10.2021 using the Markov-Switching autoregressive conditional heteroskedasticity $(\mathrm{ARCH})$ model developed by Hamilton and Susmel (1994). The current study investigates the severity of volatility on the USD/TRY exchange rate of COVID-19. 


\section{Review of Literature}

The literature summary is presented in Table 1.

Table 1

Literature

\begin{tabular}{|c|c|c|c|}
\hline AUTHORS & PERIOD & METHOD & FINDINGS \\
\hline $\begin{array}{l}\text { Iqbal, Fareed, } \\
\text { Shahzad, He, } \\
\text { Shahzad, and } \\
\text { Lina (2020) }\end{array}$ & $\begin{array}{c}21.01 .2020- \\
31.03 .2020\end{array}$ & $\begin{array}{l}\text { WTC } \\
\text { PWC } \\
\text { MWC }\end{array}$ & $\begin{array}{l}\text { Daily average temperature (hourly data), COVID-19 } \\
\text { cases, and RMB (Chinese currency) exchange rate data } \\
\text { were used in this study. Wavelet Transform Coherence } \\
\text { (WTC), Partial Wavelet Coherence (PWC) and Multiple } \\
\text { Wavelet Coherence (MWC) methodology were used to } \\
\text { analyze the collected daily data. The results revealed a } \\
\text { significant consistency between the series. shows that } \\
\text { at different time-frequency combinations, an increase } \\
\text { in temperature is insignificant to contain or slow down } \\
\text { new COVID-19 infections. The RMB exchange rate and } \\
\text { COVID-19 showed an exit phase consistency at certain } \\
\text { time-frequency points, suggesting that the outbreak had } \\
\text { a negative but limited impact on the Chinese export } \\
\text { economy. }\end{array}$ \\
\hline
\end{tabular}

Narayan and Popp (2010) two endogenous structural break unit root models, which vary over time, are used to understand the evolution of exchange rates in terms of the persistence of Covid-19 shocks. According to the

Narayan, (2020). $\quad 07.01 .2019-\quad$ NP UNIT findings, the study found that the exchange rate was not 09.04.2020 ROOT MODEL stable before the COVID-19 pandemic using the hourly Yen-US dollar exchange rate. However, Yen became stable in the COVID-19 sample, which showed that the shocks in the Yen had a temporary effect.

The effects of the COVID-19 pandemic on the returns and volatility of the BIST 100 index, the Dollar, Euro and gold prices and the volatility spread between these indicators have been studied empirically. The CCCGARCH model was applied with daily data covering the periods 01.01.2015-08.07.2020. It has been concluded

$\begin{array}{ccc}\text { Kayral and } & 01.01 .2015- & \text { CCC-GARCH } \\ \text { Tandogan } & 08.07 .2020 & \\ (2020) & \end{array}$
that all investment instruments other than the BIST 100 index is affected by the one-period delayed return of at least one different investment instruments. In addition, the pandemic process increased the volatility of investment instruments. Although a positive volatility spreads between the Dollar and the Euro from the Dollar to the Euro, the highest spread was seen in 2018, when Turkey had a political crisis with the USA.

In the study, the effects of COVID-19 on financial markets and economies were investigated. Durable Least Squares Method (DEKK) was applied with daily data covering the period of 21 January-21 May.

Şenol (2020) $\quad 21.01 .2020-\quad$ DEKK
Findings reveal that the effect of the number of cases was significant and positive, whereas that of the number of deaths was insignificant. Accordingly, COVID-19 negatively affected the BIST100 index. Although the effect of US treasury rates and volatility index on BIST100 index is positive, the effect of USD/TRY exchange rate and oil is negative. 


\begin{tabular}{|c|c|c|c|}
\hline $\begin{array}{c}\text { Benzid, and } \\
\text { Chebbi (2020) }\end{array}$ & $\begin{array}{c}01.01 .2020- \\
11.04 .2020\end{array}$ & GARCH & $\begin{array}{l}\text { The study uses a GARCH }(1,1) \text { model to explore the } \\
\text { impact of COVID-19 cases and related deaths on US } \\
\text { exchange rate volatility. The results showed that the } \\
\text { increase in the number of cases and deaths (both in logs) } \\
\text { in the USA positively affected USD/EUR, USD/Yuan, } \\
\text { and USD/LivreSterling. }\end{array}$ \\
\hline $\begin{array}{l}\text { Ayhan and } \\
\text { Abdullazade } \\
\text { (2021). }\end{array}$ & $\begin{array}{c}12.03 .2020- \\
06.11 .2020\end{array}$ & ARDL & $\begin{array}{l}\text { The effect of oil prices, gold prices and the number of } \\
\text { COVID- } 19 \text { cases on the exchange rate in the Turkish } \\
\text { economy during the COVID- } 19 \text { pandemic period was } \\
\text { investigated. For the daily data covering the period } \\
12.03 .2020-06.11 .2020 \text {, the exchange rate, oil prices, } \\
\text { gold prices and the number of COVID- } 19 \text { cases in the } \\
\text { Turkish economy are used as variables. Short and long- } \\
\text { term relationships between variables were investigated } \\
\text { by ARDL method. The study's findings reveal a } \\
\text { cointegration relationship between the variables. It has } \\
\text { been observed that oil prices affect the exchange rate } \\
\text { negatively and statistically in the long run. According } \\
\text { to the model results, a } 1 \% \text { increase in oil prices causes a } \\
0.18 \% \text { decrease in the exchange rate. }\end{array}$ \\
\hline
\end{tabular}
The study's findings reveal the nonstationarity, varying variance and structural changes in the data from January

Qasim, Iqbal, Hassan, and Ali (2021)

$01.1995-$ 01.2019

Rojanah and Zukhronah (2020) 01.1990 06.2019

MS-ARCH 1995 to January 2019. The dynamics of the data were examined in two different regimes. The results of the empirical analysis provide evidence that regime shifts are significant and that the MRS-AR model is appropriate even in the case of nonstationarity.

The results showed that the real interest rate on deposits could only explain the crisis that occurred in 1997 with the MS-ARCH(2,1) models, and the real interest rate on deposits with the MS-GARCH $(3,1,1)$ nominal exchange rate models.

\begin{tabular}{|c|c|c|}
\hline $\begin{array}{c}\text { Sugiyanto, } \\
\text { Subanti, } \\
\text { Zukhronah and }\end{array}$ & 01.1990- & MS-ARCH \\
\hline Sulandari (2020) & 12.2017 & \\
\hline
\end{tabular}

The findings showed that the coupling model for the Indonesia Composite Index (ICI) indicator is the conditional mean $\mathrm{AR}(2)$ with $\mathrm{MS}(2) \mathrm{ARCH}(1)$ or $\operatorname{SWARCH}(2,1)$. At the same time, it is among the results that the conditional average AR(1) and SWARCH (3.3) model is based on the Rupiah indicator from the Dollar (US) exchange rates.

The article uses the exponential GARCH (EGARCH) model to capture the asymmetry in the volatility clustering and the leverage effect in the exchange rate.

Epaphra (2016) 04.01.2009- GARCH The results reveal that exchange rate series exhibit 27.07.2015 E-GARCH empirical regularities, such as cluster volatility, nonstationarity, nonnormality, and serial correlation, which justifies the application of ARCH methodology. It also shows that exchange rate behavior is often influenced by previous information about the exchange rate.

The findings showed that, in general, RS models were

Panopoulou and Pantelidis(2015) more accurate than the random walk model for exchange rate forecasts, both statistically and specifically in terms of economic evaluation criteria. 


\begin{tabular}{|c|c|c|c|}
\hline $\begin{array}{l}\text { Goutte and Zou } \\
\text { (2013) }\end{array}$ & $\begin{array}{c}01.01 .2000- \\
28.05 .2012\end{array}$ & $\begin{array}{l}\text { CONTINUOUS } \\
\text { TIME } \\
\text { REGIME- } \\
\text { SWITCHING } \\
\text { MODEL }\end{array}$ & $\begin{array}{l}\text { The obtained results were compared with the non- } \\
\text { regime changing models. The findings revealed that } \\
\text { the M-S regime switching results were much closer } \\
\text { to reality than the others. In addition, the two-regime } \\
\text { model was better than the other regimens. }\end{array}$ \\
\hline $\begin{array}{l}\text { Pilbeam, and } \\
\text { Langeland } \\
\text { (2015) }\end{array}$ & 2002-2012 & GARCH & $\begin{array}{l}\text { This study divided data into two periods: } 2002-2007 \\
\text { indicated by the low volatility and } 2008-2012 \text { indicated } \\
\text { by high volatility. The findings reveal that volatility } \\
\text { forecasts significantly outperform the three GARCH } \\
\text { models in both low and high volatility periods. The } \\
\text { results strongly indicated that the foreign exchange } \\
\text { market is effectively pricing future volatility. }\end{array}$ \\
\hline Abdalla (2012) & $\begin{array}{c}01.01 .2000- \\
19.11 .2011\end{array}$ & GARCH & $\begin{array}{l}\text { The research was conducted using the GARCH approach } \\
\text { in modeling exchange rate volatility in a panel of } 19 \\
\text { Arab countries using daily observations from January } 1 \text {, } \\
2000 \text {, to November } 19,2011 \text {. } \\
\text { The results show that the sum of the permanent } \\
\text { coefficients estimated for ten of the nineteen currencies } \\
\text { exceeds } 1 \text {. Furthermore, the article concludes that } \\
\text { the class of GARCH models can adequately model } \\
\text { exchange rate volatility. }\end{array}$ \\
\hline Güloglu (2008) & $\begin{array}{l}\text { 1982:01- } \\
2006: 12\end{array}$ & MS-ARCH & $\begin{array}{l}\text { This study established the links between exchange rate } \\
\text { volatility, export and exchange rate regimes in Turkey. } \\
\text { A nonlinear Markov-Switching ARCH technique was } \\
\text { applied to monthly data covering the period 1982:01- } \\
\text { 2006:12. Findings reveal that periods of high exchange } \\
\text { rate volatility match with periods of low export } \\
\text { performance, and periods of low volatility correspond } \\
\text { to periods of high real export growth rates. }\end{array}$ \\
\hline $\begin{array}{c}\text { Güloglu and } \\
\text { Akman (2007) }\end{array}$ & $\begin{array}{c}02.03 .2001- \\
02.03 .2007\end{array}$ & $\begin{array}{c}\text { ARCH } \\
\text { GARCH } \\
\text { SWARCH }\end{array}$ & $\begin{array}{l}\text { In this study, weekly nominal exchange rate }(\mathrm{TL} / \$) \text { data } \\
\text { between } 02 / 03 / 2001 \text { and } 02 / 03 / 2007 \text { and the volatility } \\
\text { of the nominal exchange rate }(\mathrm{TL} / \$ \text { ) in Turkey were } \\
\text { analyzed using ARCH, GARCH and SWARCH models. } \\
\text { The findings show that various economic and political } \\
\text { events in Turkey and the world affect exchange rate } \\
\text { volatility and that these volatility periods are permanent. }\end{array}$ \\
\hline $\begin{array}{c}\text { Kearney and } \\
\text { Patton (2000). }\end{array}$ & $\begin{array}{c}04.1979- \\
03.1997\end{array}$ & GARCH & $\begin{array}{l}\text { The transmission of exchange rate volatility between } \\
\text { European Monetary System currencies has been studied } \\
\text { with a series of 3-, 4-, and 5-variable multivariate } \\
\text { GARCH models. Models were estimated on both daily } \\
\text { and weekly data from April } 1979 \text { to March } 1997 \text { without } \\
\text { applying the constraint of the common fixed correlation. } \\
\text { The findings show the importance of controlling } \\
\text { specification robustness in multivariate GARCH } \\
\text { modeling, that increasing temporal aggregation reduces } \\
\text { the observed volatility transfer and the sign plays a } \\
\text { dominant position in terms of volatility transfer. }\end{array}$ \\
\hline
\end{tabular}

\section{Econometric Methodology and Data}

Although any exchange rate can be used for application purposes, the USD/TRY exchange rate is preferred because TL is a currency that depreciated the most against the US dollar during the COVID-19 period. The USD/TRY data set created to capture the possible effects of COVID-19 covers the trading days between 02.03.2020 and 11.10.2021. The closed and open versions of the data are presented in Table 2 . 


\begin{tabular}{cc}
\hline USD/TRY & Data of the US Dollars/Turkish Lira (USD/TRY) Exchange Rate \\
\hline R & Data of the Returns US Dollar/Turkish Lira \\
\hline
\end{tabular}

The USD/TRY data set used in the study is retrieved from the Central Bank of the Republic of Turkey database. The return series are indicated by $\mathrm{R}$ in Table 2; they were obtained using the WinRats 8.1 program with the formula $r_{t}=\ln \left(\frac{P_{t}}{P_{t-1}}\right)$. Here, $P_{t}$, shows the sales value of dollar/TL on day $t$, whereas $r_{t}$, shows the daily return. Eviews 10.0 and WinRats 8.1 programs were used for econometric analysis.

\section{Methodology}

ARCH is a statistical model used to analyze volatility in time series. The ARCH model is used in financial analysis to predict risk by establishing a market volatility model. Engle's (1982) ARCH model is explained by the quadratic function of the past values of the shocks.

According to Engle (1982), ARCH(q) models can be written as follows:

$r_{t}=\emptyset_{0}+\sum_{i=1}^{m} \emptyset_{i} r_{t-i}+u_{t}$

$u_{t}=h_{t}^{1 / 2} \varepsilon_{t}$

$h_{t}=\alpha_{0}+\sum_{i=1}^{p} \alpha_{i} u_{t-i}^{2}$

Where $r_{t}$ is the logarithmic daily index return at time $t$, and $r_{t-i}$ is the daily index return $i$ period ago. The unconditional mean of $r_{t}$ is zero, whereas its conditional mean is $\emptyset_{i} \mathrm{r}_{t-i} \cdot u_{t}$ is a white noise process. In the generalized ARCH (GARCH) Model, the conditional variance in the $\mathrm{ARCH}(\mathrm{q})$ operation is specified only as a linear function of the past sample variances. Meanwhile, the GARCH (p, q) operation developed by Bollerslev (1986) allows lagged conditional variances to be included in the analysis. According to Bollerslev (1986), the GARCH equations can be written as follows:

$r_{t}=\emptyset_{0}+\sum_{i=1}^{m} \emptyset_{i} r_{t-i}+u_{t}$

$u_{t}=h_{t}^{1 / 2} \varepsilon_{t}$

$h_{t}=\alpha_{0}+\sum_{i=1}^{p} \alpha_{i} u_{t-i}^{2}$

The difference between the ARCH and GARCH models is that the GARCH model includes conditional variance lags $\left(h_{t}\right)$ into the conditional variance equation. ARCH and GARCH models have become important tools in analyzing time series data, especially in financial applications. In the literature, these models are preferred when the study aims to analyze and estimate volatility. 
Hamilton and Susmel (1994) determined some shortcomings in the volatility analysis of ARCH and GARCH models and developed Markow-Switching ARCH (MS-ARCH or SWARCH) as an alternative. In this sense, the SWARCH model is proposed as an alternative to Box and Jenkins' linear time series models with fixed parameters, which assume a stationary distribution (Box, 2013).

MS-ARCH models can be written as follows:

$r_{t}=\emptyset_{0}+\sum_{i=1}^{m} \emptyset_{i} r_{t-i}+e_{t}$

$e_{t}=u_{t} \sqrt{g_{(s t)}}$

$u_{t}=h_{t}^{1 / 2} \varepsilon_{\epsilon t N(0,1)}$

$h_{t}=\alpha_{0}+\sum_{i=1}^{q} \alpha_{i} u_{t-i}^{2}$

In the MS-ARCH or SWARCH $(\mathrm{k}, \mathrm{q})$ model, $S_{t}$, is called the state or regime and shows which regime the process at the time $t$ belongs to. $r_{t}$ denotes logarithmic daily index return at time $t, r_{t-i}$ is the daily index return $i$ period ago, and $u_{t}$ denotes the index return without autocorrelation. $\alpha_{0}, \ldots . \alpha_{i}$ the parameters of conditional variance equation. $h_{t}$ refers to conditional variance. And $\varepsilon_{t}$ refers to random variables that are independently distributed from each other (Hamilton and Susmel, 1994).

If the fixed transition probabilities $\left(P_{i j}\right)$ are calculated as follows, the probability of transition from one regime to another can be found. Each value in the $P$ matrix is a conditional probability:

$P_{i j}=\left[\begin{array}{ll}p_{11} & p_{12} \\ p_{21} & p_{22}\end{array}\right]$

The sum of the probabilities in the whole regime period equals 1 .

$P\left(\frac{S_{t=j}}{S_{t-1=i}}\right)=P_{i j}(i, j=1,2)$

We can calculate the residence time in the first and second regimes with the following formula:

$\frac{1}{1-P_{11}} ; \frac{1}{1-P_{22}}$

\section{Empirical Findings}

In the Turkish economy, the foreign exchange market is highly volatile. In this study, volatile periods were analyzed using two regime models: the first regime with low volatility and the second regime with high volatility. The return series of USD/ TRY data for the trading days 02.03.2020-11.10.2021 was used in the analysis. 
The results of the MS-ARCH model analysis using the USD/TRY return series for the Turkish economy during the COVID-19 period are presented in Figure 1.

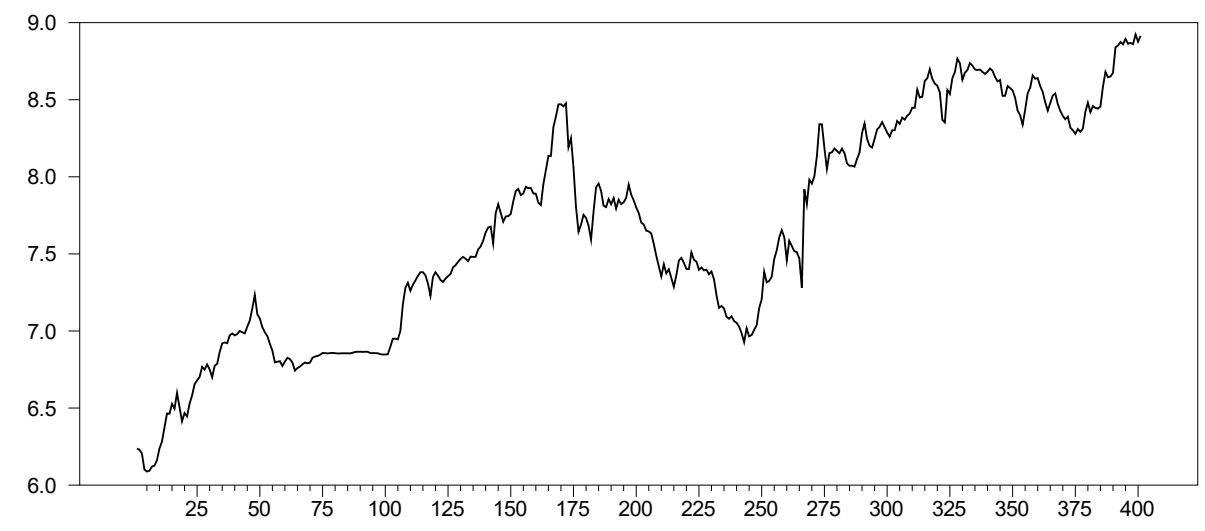

Figure 1. Time series graph related to USD/TRY

Analyzing Figure 1, we can posit that the USD/TRY series show an increasing trend and do not provide the stationary assumption sought in the series for time series analysis.

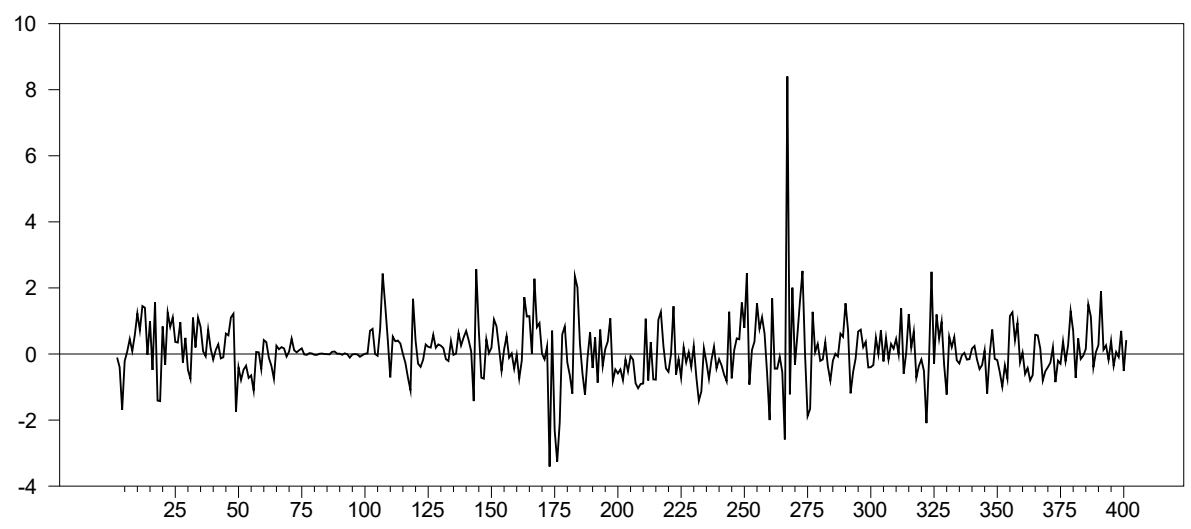

Figure 2. Return graph related to USD/TRY

Figure 2 presents the return chart of the USD/TRY exchange. Considering the chart of the USD/TRY return, remarkably, the series are stationary, and volatility clusters are experienced in some days or months. The 168th day represents November 3 , 2020, when Joe Biden won the US elections. Meanwhile, the 172nd day in the chart represents November 9, 2020, the first trading day when Naci Agbal was appointed as the Chairman of the Central Bank. Days 209 And 210 Represent December 30 and 31 , respectively. During these dates, 3 million doses of vaccine were delivered to 
Turkey in two parts. Moreover, the 265th day represents the date of dismissal of the Central Bank Governor, Naci Agbal, on March 20, 2021.

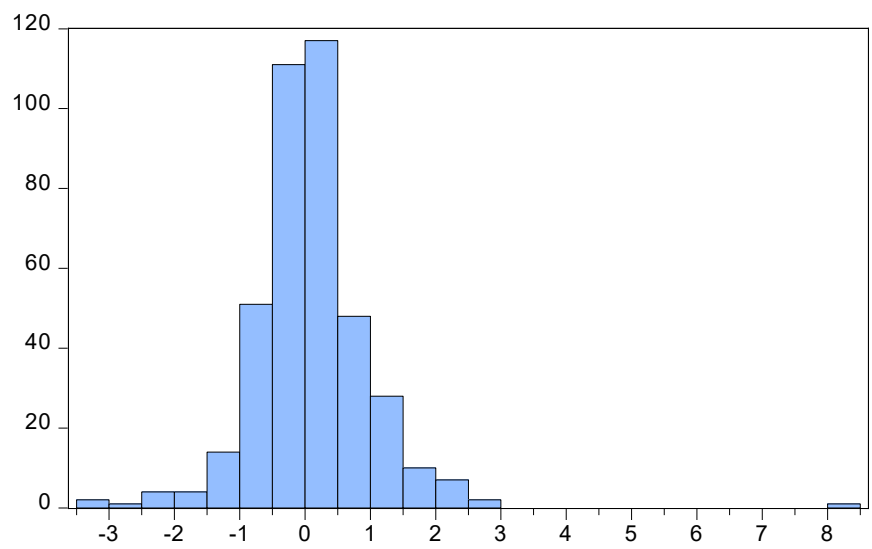

\begin{tabular}{|c|c|}
\hline $\begin{array}{l}\text { Series: } R \\
\text { Sample } 140 \\
\text { Observation }\end{array}$ & \\
\hline Mean & 0.089283 \\
\hline Median & 0.013309 \\
\hline Maximum & 8.401931 \\
\hline Minimum & -3.406632 \\
\hline Std. Dev. & 0.913528 \\
\hline Skewness & 1.770815 \\
\hline Kurtosis & 20.47100 \\
\hline Jarque-Bera & 5296.316 \\
\hline Probability & 0.000000 \\
\hline
\end{tabular}

Figure 3. Histogram statistics

The results of histogram statistics in Figure 3 shows that the average return of the USD/TRY return series is positive. The maximum return was calculated as $8.4 \%$, the minimum return is $-3.4 \%$, the skewness coefficient is 1.770815 , and the kurtosis coefficient is 20.47100 . The most critical indicators of the normal distribution are kurtosis and skewness values. If the kurtosis value of the series is greater than 3 (leptokurtosis), fat tails occur in which the values are concentrated in the extreme region, and if the skewness value of the series is different from 0 , asymmetric effects occur. The skewness coefficient is positive; hence, the series is skewed to the right, and the left tail is long. Meanwhile, looking at the kurtosis coefficient, we can see that the series does not follow a horizontal course, but it is steep and pointed, because the number 20.47100 obtained is greater than 3. As shown from the descriptive statistics, the return series has the characteristics of asymmetry (skewness $=1.770815$ ) and fat tail (kurtosis $=20.47100)$ in the period. The Jarque-Bera test statistic shows that the USD/TRY return series does not follow the normal distribution. Many studies such as Kearney and Patton (2000) and Abdalla (2012) pointed out that financial data do not provide the assumption of normal distribution.

According to the unit root test results shown in Table 3, when the test statistics of the return series are compared with the critical values, it is concluded that the critical values are constant at the $1 \%$ significance level, and stationary at constant and trended values.

Results for unit root tests are shown in Table 3. 


\begin{tabular}{|c|c|c|c|c|c|c|}
\hline \multicolumn{7}{|c|}{ USD/TRY RETURN } \\
\hline & Test & Difference & Percentage & Critical Value & t-Statistic & Probability \\
\hline \multirow{6}{*}{ 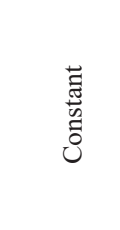 } & \multirow{3}{*}{$\mathrm{ADF}$} & \multirow{3}{*}{ Level } & $1 \%$ & -3.446525 & \multirow{3}{*}{-19.07136} & \multirow{3}{*}{0.0000} \\
\hline & & & $5 \%$ & -2.868565 & & \\
\hline & & & $10 \%$ & -2.570578 & & \\
\hline & \multirow{3}{*}{ PP } & \multirow{3}{*}{ Level } & $1 \%$ & -3.446525 & \multirow{3}{*}{-19.18242} & \multirow{3}{*}{0.0000} \\
\hline & & & $5 \%$ & -2.868565 & & \\
\hline & & & $10 \%$ & -2.570578 & & \\
\hline \multirow{6}{*}{ 苞怘 } & \multirow{3}{*}{$\mathrm{ADF}$} & \multirow{3}{*}{ Level } & $1 \%$ & -3.981225 & \multirow{3}{*}{-19.05600} & \multirow{3}{*}{0.0000} \\
\hline & & & $5 \%$ & -3.421126 & & \\
\hline & & & $10 \%$ & -3.133309 & & \\
\hline & \multirow{3}{*}{ PP } & \multirow{3}{*}{ Level } & $1 \%$ & -3.981225 & \multirow{3}{*}{-19.16482} & \multirow{3}{*}{0.0000} \\
\hline & & & $5 \%$ & -3.421126 & & \\
\hline & & & $10 \%$ & -3.133309 & & \\
\hline
\end{tabular}

H0: USD/TRY return has a unit root.

H1: USD/TRY return has not a unit root. (USD/TRY Return Stationary)

According to the ADF and PP unit root test results, we have sufficient evidence to reject the null hypothesis that the series contains a unit root because it is stationary, that is, I (0). In this respect, the stability condition required for time series analysis is met. After tables 4 and 5 below, regression results using the Least Squares Method can be seen in table 6 . Table 6 contains the diagnostic tests of the study. Autocorrelation and partial correlation results are given in Table 7 after Table 6 . Table 7 also shows that the analyzed series is stationary.

The results of the two regimes MS-ARCH models, which considers the asymmetric effect, are shown in Table 4.

Table 4

MS-ARCH (2,2) model estimation results

\begin{tabular}{|c|c|c|c|}
\hline \multicolumn{4}{|l|}{ MAXIMIZE - Estimation by BFGS } \\
\hline Convergence in 41 Iterations. & \multicolumn{3}{|c|}{ Final criterion was $0.0000057<=0.0000100$} \\
\hline Usable Observations & \multicolumn{3}{|c|}{397} \\
\hline Function Value & \multicolumn{3}{|c|}{-404.4932} \\
\hline \multicolumn{4}{|c|}{$h_{t}=\alpha+\beta+A R C H(1)+A R C H(2)+G V(1)+G V(2)+X I+\theta(1,1)+\theta(1,2)+\varepsilon_{t}$} \\
\hline Variable & Coeff & T-Stat & Signif \\
\hline 1. $\alpha$ & 0.000379464 & 0.03882 & 0.96903323 \\
\hline 2. $\beta$ & 0.132536675 & 3.64649 & 0.00026585 \\
\hline 3. $\mathrm{ARCH}(1)$ & 0.234513592 & 2.58948 & 0.00961205 \\
\hline 4. $\mathrm{ARCH}(2)$ & 0.150026994 & 2.63189 & 0.00849114 \\
\hline 5. GV(1) & 0.001938346 & 3.58145 & 0.0003417 \\
\hline 6. $G V(2)$ & 0.334351525 & 7.54341 & 0.00000 \\
\hline 7. XI & 0.642561413 & 3.21239 & 0.00131638 \\
\hline 8. $\theta(1,1)$ & 2.519864916 & 3.70636 & 0.00021026 \\
\hline 9. $\theta(1,2)$ & -5.043600131 & -7.27255 & 0.00000 \\
\hline
\end{tabular}

$* \alpha$ and $\beta$ are the parameters of the mean model. $\alpha$;alpha; constant parameter of the mean model, $\beta$; beta, parameter of the one period ago value of the return, $\theta$; theta, regime switching parameters. 
For the first regime, the GV(1) parameter shows the regime change in the variance for the low-volatility regime. Meanwhile, for the second regime, the parameter $\mathrm{GV}(2)$ shows the regime change in the variance for the high volatile regime. XI parameter shows the asymmetric effect, whereas $\operatorname{THETA}(1,1)$ and $\operatorname{THETA}(1,2)$ are transition parameters. All parameters were statistically significant.

Looking at the parameters showing the regime change in variance, we found low volatile regime $\mathrm{GV}(1)=0.001938346$ and high volatility regime $\mathrm{GV}(2)=0.334351525$. In this context, $\mathrm{GV}(2)$ is approximately 172 times riskier than GV(1). The high volatile (i.e., the second regime) showed 172 times more volatile behavior than the low volatile (i.e., the first regime).

These results show that in the first regime with low volatility, the probability of USD/TRY being high is 0.001 , whereas in the second regime with high volatility, the probability of being high in USD/TRY is 0.33 .

Table 5

Regime switching probability estimates

\begin{tabular}{cccc}
\hline & & & \\
Regime switching probability estimates & Regime 1 & Regime 2 & Trading Day \\
Regime 1 & 0.92552 & 0.00641 & 13 \\
Regime 2 & 0.07448 & 0.99359 & 156 \\
\hline
\end{tabular}

The results obtained from the probabilities present the following:

- p11: The probability of staying in low volatility while in low-volatility regime 0.92

- p21: The probability of switching from high volatility to low-volatility regime 0.07

- p12: The probability of switching from low volatility to high volatility regime 0.006

- $\mathrm{p} 22$ : The probability of staying in high volatility regime 0.99

The volatility is high in the transition probabilities $t-1$ period, and the probability of high volatility in this period is also strong. Likewise, the low volatility in the $t-1$ period means that the probability of low volatility in this period is strong.

With the prime diagonal elements of this matrix, namely p11 and p22 (in the first and second regimes, respectively), the number of trading days spent in that regime, that is, the number of periods, can be calculated. When $1 /(1-p 11)$ is made for the number of periods in which it is traded in the first regime, 13.42642 is calculated. In this respect, when the result is rounded, we can say that the first regime will last in approximately 13 days. When $1 /(1-\mathrm{p} 22)$ is made for the number of periods in which it is traded in the second regime, it is 156.0062. Thus, when the result is rounded, the second regimen will last in approximately 156 days. Looking at the results, we 
can determine that the last time of regime 2 is 12 times longer than the last time of regime 1 .

In summary, when USD/TRY starts exhibiting low volatility, it may take up to 13 trading days. Meanwhile, when it starts exhibiting high volatile behavior, it will take 156 trading days to end. In this context, the findings reveal that the USD/TRY return series exhibits a persistent behavior in terms of its persistence in the high volatile regime. Therefore, these results provide the investor trading in the foreign exchange market with the opportunity to make an investment decision considering the duration of the USD/TRY series in these two regimes.

\section{Conclusion}

The COVID-19 pandemic, which emerged in the last months of 2019, deeply affected the global financial markets and many sectors. The literature has specified that the pandemic has a great impact on volatility, especially on investor behavior.

In the trading days between March 2020 and October 2021, when the first COVID-19 case appeared in Turkey, the effect of volatility was estimated with the MS-ARCH model using USD/TRY exchange rate returns. Two volatility regimes, namely, low volatility and high volatility, were used in the study. The findings show that the COVID-19 pandemic and various economic and political events in Turkey and the world affect exchange rate volatility; moreover, these volatility periods are permanent. It also shows that the USD/TRY return series has a strong regime dependency and high volatility. Through these findings, we conjectured that the USD/TRY return series is intended to persist in the high-risk regime in terms of its persistence in the low-volatility regime throughout the pandemic. Finally, the asymmetric effect indicates that developments in both global and domestic markets affect exchange rate volatility.

The base policy proposition of these results is that estimating the exchange rate volatility is important for asset pricing and risk management, as exchange rate volatility can increase transaction costs and reduce gains in international trade. The article adds to the existing literature by explaining volatility modeling with recent daily exchange rate returns during the COVID-19 pandemic.

Hakem Değerlendirmesi: Dış bağımsız.

Çıkar Çatışması: Yazar çıkar çatışması bildirmemiştir.

Finansal Destek: Yazar bu çalışma için finansal destek almadığını beyan etmiştir.

Peer-review: Externally peer-reviewed.

Conflict of Interest: The author has no conflict of interest to declare.

Grant Support: The author declared that this study has received no financial support. 


\section{References}

Abdalla, S. Z. S. (2012). Modelling exchange rate volatility using GARCH models: Empirical evidence from Arab countries. International Journal of Economics and Finance, 4(3), 216-229.

Ayhan, F., \& Abdullazade, M. (2021). Türkiye Ekonomisinde Covid-19 Salgını sonrasında Petrol ve Altın Fiyatları ile Vaka Sayılarının Döviz Kuru Üzerindeki Etkileri. Yaşar Üniversitesi E-Dergisi, 16(62), 509-523.

Benzid, L., \& Chebbi, K. (2020). The impact of COVID-19 on exchange rate volatility: evidence through GARCH model. Available at SSRN 3612141.

Box G. (2013). Box and Jenkins: Time Series Analysis, Forecasting and Control. In: A Very British Affair. Palgrave Advanced Texts in Econometrics. Palgrave Macmillan, London. https://doi. org/10.1057/9781137291264_6

Bollerslev, T. (1986), Generalized Autoregressive Conditional Heteroskedasticity, ARCH Selected Readings Advanced Texts in Econometrics, 44, 48.

Dieobold, F. X. (1986). Modeling the persistence of conditional variances: A comment. Econometric Reviews, 5(1), 51-56.

Epaphra, M. (2016). Modeling exchange rate volatility: Application of the GARCH and EGARCH models. Journal of Mathematical Finance, 7(1), 121-143.

Goutte, S., \& Zou, B. (2013). Continuous time regime-switching model applied to foreign exchange rate. Math. Finance Lett., Article-ID 8.

Güloğlu, B., \& Akman, A. (2007). Türkiye'de döviz kuru oynaklığının SWARCH Yöntemi ile analizi. Finans Politik \& Ekonomik Yorumlar, 44(512), 43-51.

Güloğlu, B. (2008). Exports and volatility of exchange rate under alternative exchange rate regimes: The case of Turkey. In Proc. The International Conference on Policy Modeling, EcoMod, Berlin.

Hamilton, J. D., \& Susmel, R. (1994). Autoregressive conditional heteroskedasticity and changes in regime. Journal of econometrics, 64(1-2), 307-333.

Iqbal, N., Fareed, Z., Shahzad, F., He, X., Shahzad, U., \& Lina, M. (2020). The nexus between COVID-19, temperature and exchange rate in Wuhan city: new findings from partial and multiple wavelet coherence. Science of The Total Environment, 729, 138916.

İşler, İ. İ., \& Güven, A. (2021). Covid 19 Küresel Salgınının BIST 100 Endeksi Üzerindeki Etkileri. Politik Ekonomik Kuram, 5(1), 63-77.

Kayral, İ. E., \& Tandoğan, N. Ş. (2020). BİST100, Döviz Kurları ve Altının Getiri ve Volatilitesinde COVID-19 Etkisi. Gaziantep University Journal of Social Sciences, 19, 687-701.

Kearney, C., \& Patton, A. J. (2000). Multivariate GARCH modeling of exchange rate volatility transmission in the European monetary system. Financial Review, 35(1), 29-48.

Lamoureux, C. G., \& Lastrapes, W. D. (1990). Persistence in variance, structural change, and the GARCH model. Journal of Business \& Economic Statistics, 8(2), 225-234.

Nafisah, N., \& Pratiwi, H. (2020). Early detection of Indonesian financial crisis using combination of volatility and Markov switching models based on indicators of real exchange rate and M2/ foreign exchange reserves. In Journal of Physics: Conference Series (Vol. 1563, No. 1, p. 012001). IOP Publishing.

Narayan, P. K. (2020). Has COVID-19 changed exchange rate resistance to shocks?. Asian Economics Letters, 1(1), 17389.

Panopoulou, E., \& Pantelidis, T. (2015). Regime-switching models for exchange rates. The European Journal of Finance, 21(12), 1023-1069. 
Pilbeam, K., \& Langeland, K. N. (2015). Forecasting exchange rate volatility: GARCH models versus implied volatility forecasts. International Economics and Economic Policy, 12(1), $127-$ 142.

Qasim, T. B., Iqbal, G. Z., Hassan, M. U., \& Ali, H. (2021). Application of Markov Regime Switching Autoregressive Model to Gold Prices in Pakistan. Review of Economics and Development Studies, 7(3), 309-323.

Rojanah, D., \& Zukhronah, E. (2020). Financial crisis prediction in Indonesia using combined of volatility and Markov switching models based on real interest rate on deposit and nominal exchange rate indicators. In Journal of Physics: Conference Series (Vol. 1563, No. 1, p. 012002). IOP Publishing.

Sugiyanto., Slamet I., Zukhronah E., Subanti S. and Sulandari W. (2018). Financial Crisis Model in Indonesia Based on Indonesia Composite Index (ICI) and Dollar (US) Exchange Rates to Rupiah Indicators. In Proc. The International Conference on Mathematics and Islam - Volume 1: ICMIs, ISBN 978-989-758-407-7, pages 46-51. DOI: 10.5220/0008517000460051

Şenol, Z. (2020). COVID-19 krizi ve finansal piyasalar. Para ve finans, 75-124.

Weiss, M., Schwarzenberg, A., Nelson, R., Sutter, K. M., \& Sutherland, M. D. (2020). Global economic effects of COVID-19. Congressional Research Service.

Yıldız Contuk, F. (2021). Covid -19'un Borsa İstanbul Üzerindeki Etkisi: Bir ARDL Sınır Testi Modeli. Muhasebe ve Finansman Dergisi, 89(1), 101-112. DOI: 10.25095/mufad.852088 
Table 6

Linear regression estimation by least squares

Dependent Variable

$t-1$

Usable Observations

399

Degrees of Freedom

397

0.0019047

$-0.0006094$

0.0114529

0.089775683

0.914622004

0.914900665

332.3061607

0.7576

0.3846095

$-529.667$

2.0065

Table 7

Correlations of Series $R$

\begin{tabular}{|c|c|c|c|c|c|c|c|c|c|}
\hline \multicolumn{10}{|c|}{ Autocorrelations } \\
\hline 1 & 2 & 3 & 4 & 5 & 6 & 7 & 8 & 9 & 10 \\
\hline 0.04363 & 0.0805 & -0.05954 & 0.05118 & 0.07166 & 0.0445 & -0.09054 & -0.10433 & -0.09628 & 0.02493 \\
\hline 11 & 12 & 13 & 14 & 15 & 16 & 17 & 18 & 19 & 20 \\
\hline-0.01055 & 0.09739 & -0.00137 & 0.00881 & -0.04825 & 0.04784 & -0.01594 & -0.01144 & 0.02236 & -0.00663 \\
\hline 21 & 22 & 23 & 24 & 25 & 26 & 27 & 28 & 29 & 30 \\
\hline 0.06406 & -0.00294 & 0.09329 & -0.0321 & -0.0455 & -0.03172 & 0.02646 & 0.00212 & 0.0397 & 0.04664 \\
\hline 31 & 32 & 33 & 34 & 35 & 36 & 37 & 38 & 39 & 40 \\
\hline 0.0016 & -0.01363 & 0.1053 & -0.03393 & -0.08194 & -0.07791 & 0.03802 & 0.0301 & 0.05007 & -0.04324 \\
\hline \multicolumn{10}{|c|}{ Partial Autocorrelations } \\
\hline 1 & 2 & 3 & 4 & 5 & 6 & 7 & 8 & 9 & 10 \\
\hline 0.04363 & 0.0805 & -0.05954 & 0.05118 & 0.07166 & 0.0445 & -0.09054 & -0.10433 & -0.09628 & 0.02493 \\
\hline 11 & 12 & 13 & 14 & 15 & 16 & 17 & 18 & 19 & 20 \\
\hline-0.01055 & 0.09739 & -0.00137 & 0.00881 & -0.04825 & 0.04784 & -0.01594 & -0.01144 & 0.02236 & -0.00663 \\
\hline 21 & 22 & 23 & 24 & 25 & 26 & 27 & 28 & 29 & 30 \\
\hline 0.06406 & -0.00294 & 0.09329 & -0.0321 & -0.0455 & -0.03172 & 0.02646 & 0.00212 & 0.0397 & 0.04664 \\
\hline 31 & 32 & 33 & 34 & 35 & 36 & 37 & 38 & 39 & 40 \\
\hline 0.0016 & -0.01363 & 0.1053 & -0.03393 & -0.08194 & -0.07791 & 0.03802 & 0.0301 & 0.05007 & -0.04324 \\
\hline
\end{tabular}

